\title{
Effect of Arbuscular Mycorrhiza Fungal Inoculation with Compost on Yield and Phosphorous Uptake of Berseem in Alkaline Calcareous Soil
}

\author{
Bismillah Jan', Amjad Ali2*, Fazli Wahid', Syed Noor Muhammad Shah ${ }^{3,4}$, \\ Asif Khan', Farmanullah Khan ${ }^{5}$ \\ ${ }^{1}$ Department of Soil and Environmental Science, University of Agriculture, Peshawar, Pakistan \\ ${ }^{2}$ College of Resource and Environment, Northwest A\&F University, Yangling, China \\ ${ }^{3}$ Department of Horticulture, Gomal University, D.I. Khan, Pakistan \\ ${ }^{4}$ College of Horticulture, Northwest A\&F University, Yangling, China \\ ${ }^{5}$ Directorate of Soil and Water Conservation, Peshawar, Pakistan \\ Email: amjadali@aup.edu.pk
}

Received 14 February 2014; revised 25 March 2014; accepted 9 April 2014

Copyright (C) 2014 by authors and Scientific Research Publishing Inc.

This work is licensed under the Creative Commons Attribution International License (CC BY).

http://creativecommons.org/licenses/by/4.0/

(c) (i) Open Access

\section{Abstract}

An experiment was conducted in pots under natural conditions in alkaline calcareous soil to determine berseem (Trifolium alexandrium) yield and $P$ uptake as affected by Arbuscular mycorrhizal fungi (AMF) inoculation with compost prepared from fresh animal dung and rock phosphate. Data indicated that berseem shoot and roots yields increased significantly $(P \leq 0.05)$ by inoculation of indigenous mycorrhiza (AMF-I) and half dose of compost. Shoot yield increased as $98 \%$ and $76 \%$ roots yield as $60 \%$ and $52 \%$ over control and $\mathrm{N}$ and $\mathrm{K}$ fertilizers. Maximum and significantly $(P \leq 0.05)$ increased plant $N$ and $P$ uptake by berseem was observed in the treatment inoculated by commercial mycorrhiza (AMF-II) with full dose of compost followed by the inoculation of AMF- II with half dose of compost. Plants uptake of $\mathrm{Cu}, \mathrm{Mn}$ and Fe was improved significantly $(\mathrm{P} \leq 0.05)$ by the inoculation of AMF-II with half dose of compost, while $\mathrm{Zn}$ uptake was increased in the treatment of AMF-II inoculation with full dose of compost. Maximum and significantly $(P \leq 0.05)$ increased soil spores density of AMF as 27 spores per 20 g soil was noted by inoculation of AMF-I with half dose of compost, while maximum roots infection intensity in berseem was observed by the inoculation of AMF-I with full dose of compost. Results suggest that inoculation of AMF with compost has potential to improve berseem yields and plants nutrients uptake under given soil conditions. 
Keywords

\author{
AMF Inoculation; Alkaline Calcareous Soil; Berseem Crop; Compost; Plants Nutrients \\ Uptake and Yield
}

\title{
1. Introduction
}

Mycorrhizal fungi are beneficial symbiotic microorganisms with their extra matrical hyphae, which increase growth and yield of most crop plant through increase absorption of relatively immobile elements in soil such as $\mathrm{P}, \mathrm{Cu}$ and $\mathrm{Zn}$ by substantially extending the area of absorption beyond that of root hairs [1]. Enhanced uptake of $\mathrm{P}$ is generally regarded as the most important benefit that AMF provide to their host plant and soil $\mathrm{P}$ status is often the main controlling factor in the plant-fungal relationship [2]. Phosphorus plays a vital role in plant growth and is the second essential macronutrient after Nitrogen. It plays an important role in root elongation, root proliferation and P deficiency effect root architecture [3]. Plants required $\mathrm{P}$ in relatively large amount range from $0.2 \%-0.8 \%$ of plant dry matter yield [4]. Phosphorus found in organic, inorganic or mineral forms. Organic form consists of plant and animals residues and microbes. Large fraction of total soil phosphorus is in organic form and is not directly available to the plant [5]. Phosphorus deficiency is one of major limiting factors in plant growth and its productivity in many ecosystems [6]. Poor availability of $\mathrm{P}$ is due to the presence of Ca in neutral to alkaline $\mathrm{pH}$ and $\mathrm{Fe}$ and $\mathrm{Al}$ in acidic soil, which leads to the fixation of $\mathrm{P}$ and thus unavailable to the plant [7] Composting is environmental friendly and cost effective technique of waste recycling [8]. Composts are prepared from roots, leaves, straw, stems and crop residues etc. through microorganism's action. These materials undergo decomposition under temperature in pits, heaps with adequate moisture. About 3 - 6 months are generally required for this process when brown to dark brown material with no odd smell is obtained then composts is prepared. Rock phosphate (RP) is the raw material of P fertilizer. It is estimated that the world's reserve would last for only 90 years [9]. The expected global peak of $\mathrm{P}$ production is predicted to occur around 2030 [10]. Rock phosphate is slowly available P source with total concentration of P relatively high (more than 15\%) and soluble concentration is relatively low (less than 1\%). The agronomic performance of the rock phosphate applied directly as phosphatic fertilizers depends on different factors and their interaction. These factors include the physical and chemical properties of RP, plant species and cropping system, soil and climatic factors and farm management practices. Berseem (Trifolium alexandrinum), the most common winter and spring fodder in many parts of Pakistan is low in phosphorus contents (0.14\%) and abundant in calcium (1.44\%). Owing to a wide calcium phosphorus ratio, animals fed predominantly on berseem unless supplemented with some rich source of phosphorus like grains may suffer from phosphorus deficiency syndromes [11]. Keeping in view the importance of AMF in nutrients solubilization and crop production, this study was initiated to determine the effects of AMF inoculation with compost on the yield and plants nutrients uptake of berseem.

\section{Materials and Methods}

A pot experiment was conducted under natural conditions to determine yield and $\mathrm{P}$ uptake of berseem (Trifolium alexandrium) as influenced by AMF inoculation with compost. Berseem crop was grown in pots summer, 2011with three replications in completely randomized design (CRD) in green house. Surface soil sample was collected at depth of $0-30 \mathrm{~cm}$ from research farm of the University of Agriculture, Peshawar and filled in pots at the rate of $3 \mathrm{~kg}$ per pot. Physicochemical characteristics (Table 1) of the soil under investigation were determined for texture by method described by Koehler [12], soil pH by procedure of McClean [13], lime was determined by method described by Richard [14]. For determination of organic matter method was used as described Nelson and Sommers [15]. Soil total N was determined by Kjeldhal method of Bremner [16]. P and K were determined by method used by Soltanpour and Schwab [17]. The soil under investigation was clay loam in texture and alkaline in nature, low in O.M, N contents and AB-DTPA extractable P and calcareous in nature. Compost was prepared from the fresh animal dung and rock phosphate (RP) of Hazara area. Fresh animal dung was mixed with RP at the ratio of 2:1 (Dung:RP) according to the method as described by Hauck [18]. Dose of $\mathrm{N}$ was applied at the rate of $120 \mathrm{~kg} \mathrm{~N} \mathrm{ha}^{-1}$ in three splits doses as Urea. Phosphorous was applied as SSP or compost at the rate of $90 \mathrm{~kg} \mathrm{P} \mathrm{ha}^{-1}$ and $\mathrm{K}$ as potassium sulphate at the rate of $60 \mathrm{~kg} \mathrm{~K} \mathrm{ha}^{-1}$. All P and $\mathrm{K}$ fertilizers were ap- 
plied at sowing time. Pots were randomized completely with one week interval to minimize the side effect. All agronomic practices were strictly followed uniformly throughout the growing season for optimum crop growth. Mycorrhizal spores extracted from $100 \mathrm{~g}$ fresh soil of sorghum crop grown for the production of AMF inoculum in same soil conditions were used as indigenous inoculum. This indigenous AMF inoculum was dominated with Glomus intraradices, where as the spores of $G$. fasiculatum and G. mossea were present in minor quantity. These spores were inoculated uniformly in the pots of AMF inoculation at the rate of 100 spore pot $^{-1}$. The commercial AMF inoculum was received from BioMyc ${ }^{\mathrm{TM}}$, Germany which consists of species Glomusintraradices. This inoculum was inoculated at the rate of $10 \mathrm{ml} \mathrm{pot}^{-1}$ by the method as described by BioMyc Environment GmbH, Germany [19]. Twenty seeds of berseem were sown initially in each pot and were thinned to ten plants per pot after germination. Plants were harvested at maturity stage. Post harvest shoot dry matter yield of berseem was recorded in each treatment after drying. Plants samples were digested and analyzed according to the procedure as described by Walsh [20]. Plants N, P and micronutrients concentrations of berseem were determined. To avoid the effect of dilutions or concentrations caused by variation in wheat plants yield, the nutrients concentration were converted into total amount of nutrients uptake plants by multiplying nutrient concentrations with total dry matter in $\mathrm{kg} \mathrm{ha}^{-1}$ by the procedure as described by Barber [21]. Roots of plants were removed from the soil, washed and dried at $65^{\circ} \mathrm{C}-70^{\circ} \mathrm{C}$ till constant weight and root dry weights were recorded. Fresh soil and roots samples were also collected and stored at $4^{\circ} \mathrm{C}$ for the determination of spores density and AMF root infection intensity. Plants' $\mathrm{N}$ concentration was determined by Kjeldah Method [22], while $\mathrm{P}$ and micronutrients concentration by Wet-Digestion Method [23]. Post harvest total soil N content was determined by kjeldhal method of Bremner [16]. AB-DTPA extractable P, Cu, Fe, Zn and Mn were analyzed by the method as described by Soltonpour and Schwabe [17]. Phosphorous was measured using Lambda 35 pectrophotometer and micronutrients by Perkin Elmer atomic absorption spectrophotomer. The AMF spores were isolated from soil by wet-sieving and decanting techniques as described by Brundrett [24]. Infection intensity of AMF in the roots was determined according to the procedures of Philips and Hayman [25] and Koske and Gemma [26]. Isolated spores were identified according to the procedure described by Schenck and Parez [27]. Statistical analysis of the collected data was carried out by conducting ANOVA and the means were compared by LSD test [28].

\section{Results and Discussion}

An experiment was conducted in pots in Institute of Biotechnology and Genetics Engineering (IBGE), the University of Agriculture, Peshawar in summer 2011to determine berseem (Trifolium alexandrium) yield and yield components and plants nutrients uptakes as influenced by AMF and compost prepared from fresh animal dung and RP. Physicochemical characteristics of soil are shown in Table 1.

\subsection{Berseem Yield and Yield Components}

Data on shoots and roots yields of berseem as influenced by AMF inoculation with compost are presented in Table 2. Data showed that maximum shoot dry matter yield of $4333 \mathrm{~kg} \mathrm{ha}^{-1}$, was recorded in the treatment of inoculation of indigenous mycorrhiza (AMF-I) with half dose of compost, which was significantly $(\mathrm{P} \leq 0.05)$ higher by $98 \%$ and $76 \%$, respectively over control and $\mathrm{N}$ and $\mathrm{K}$ fertilizers (Figure 1). The data indicated that highest berseem roots dry weight of $793 \mathrm{~kg} \mathrm{ha}^{-1}$ was observed in the inoculation of AMF-I with half dose of compost, and was significantly $(\mathrm{P} \leq 0.05)$ increased as $60 \%$ and $52 \%$, respectively over control and $\mathrm{N}$ and $\mathrm{K}$ fertilizers (Figure 2). Habashy et al. [29] reported that the highest grain production was obtained in the treatment of AMF inoculation with compost combination with 15 and $30 \mathrm{~kg} \mathrm{P}_{2} \mathrm{O}_{5} \mathrm{fed}^{-1}$. El-Goud [30] found that highest yield of maize plants was found in the treatment of inoculation of AMF with the application of $75 \%$ compost and $100 \% \mathrm{~N}$ of recommended dose of nitrogen fertilizer. El-Sayed et al. [31] reported that the highest yield was obtained in the treatment 75\% compost of recommended dose and NPK fertilizer application. Filho [32] reported maximum growth and shoot dry matter yield in jack-bean and pigeon-pea inoculated with AMF and compost than AMF inoculation or compose alone. Sharif and Jan [33] found that shoot and root dry matter were significantly increase by the inoculation of AMF with rock phosphate. Sharif et al. [34] reported that shoot and root dry mater yields of wheat crop significantly increased with inoculation of AMF alone and in combination with poultry manure (PM), farmyard manure (FYM) and humic acid (HA). 
Table 1. Physico chemical characteristics of soil under investigations.

\begin{tabular}{ccc}
\hline Property & Units & Concentration \\
Sand & $\%$ & 28.4 \\
Silt & $\%$ & 66.2 \\
Clay & $\%$ & 5.4 \\
Textural class & - & Silt loam \\
pH & - & 7.56 \\
EC & $\mathrm{d} \mathrm{Sm}^{-1}$ & 2.76 \\
Lime & $\%$ & 16.5 \\
O.M content & $\%$ & 0.73 \\
Total N content & $\%$ & 0.08 \\
P (AB-DTPA extractable) & $\mathrm{mg} \mathrm{kg}^{-1}$ & 2.25 \\
\hline
\end{tabular}

Table 2. Effect of AMF inoculation with compost on shoots and root dry matter yield of berseem.

\begin{tabular}{ccc}
\hline Treatments & Shoot dry matter & Root dry matter \\
\cline { 2 - 3 } Control (No fertilizer) & & yield $\left(\mathrm{kg} \mathrm{ha}^{-1}\right)$ \\
N and K fertilizer ( Basal dose) & $2094 \mathrm{c}^{*}$ & $496 \mathrm{e}^{*}$ \\
Full dose of compost & $2348 \mathrm{c}$ & $521 \mathrm{e}$ \\
Indigenous AMF (AMF-I) & $3033 \mathrm{~b}$ & $703 \mathrm{~cd}$ \\
Commercial AMF (AMF-II) & $2843 \mathrm{~b}$ & $676 \mathrm{~d}$ \\
Half dose of compost + AMF-I & $2863 \mathrm{~b}$ & $793 \mathrm{a}$ \\
Half dose of compost + AMF-II & $4333 \mathrm{a}$ & $770 \mathrm{ab}$ \\
Full dose of compost + AMF-I & $4150 \mathrm{a}$ & $749 \mathrm{ab}$ \\
Full dose of compost + AMF-II & $4051 \mathrm{a}$ & $743 \mathrm{bc}$ \\
Full dose of SSP & $4033 \mathrm{a}$ & $742 \mathrm{bc}$ \\
\hline
\end{tabular}

"Means with different letter(s) in columns are significantly different at P $\leq 0.05$. N-P-K $=120-90-60 \mathrm{~kg} \mathrm{ha}^{-1}$, respectively, compost $=4500 \mathrm{~kg}^{-1}$, AMF-1 $=70$ spores pot $^{-1}$, AMF-II $=10 \mathrm{ml}$ pot

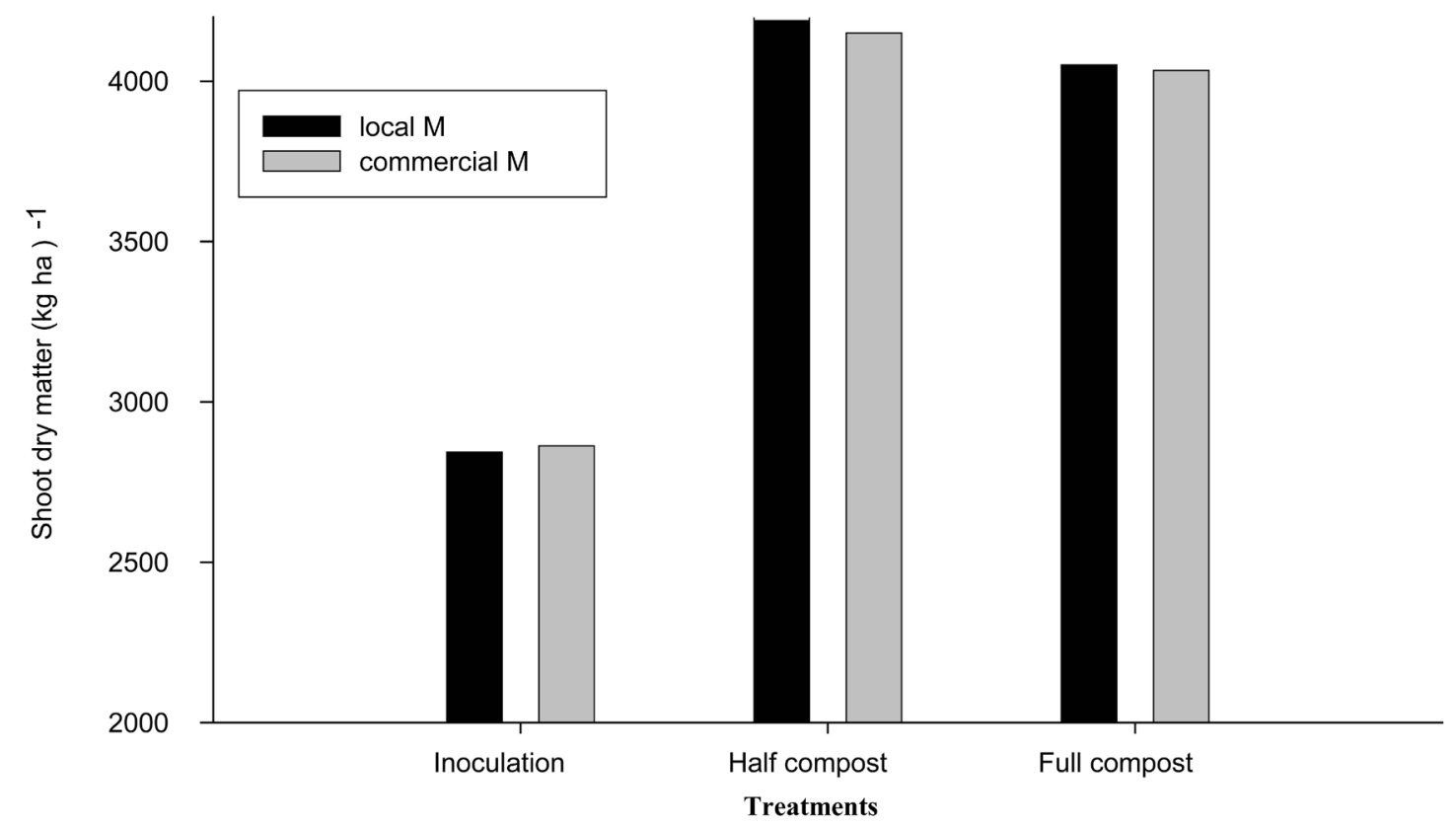

Figure 1. Effect of AMF inoculation with compost on shoot dry matter yield of berseem. 


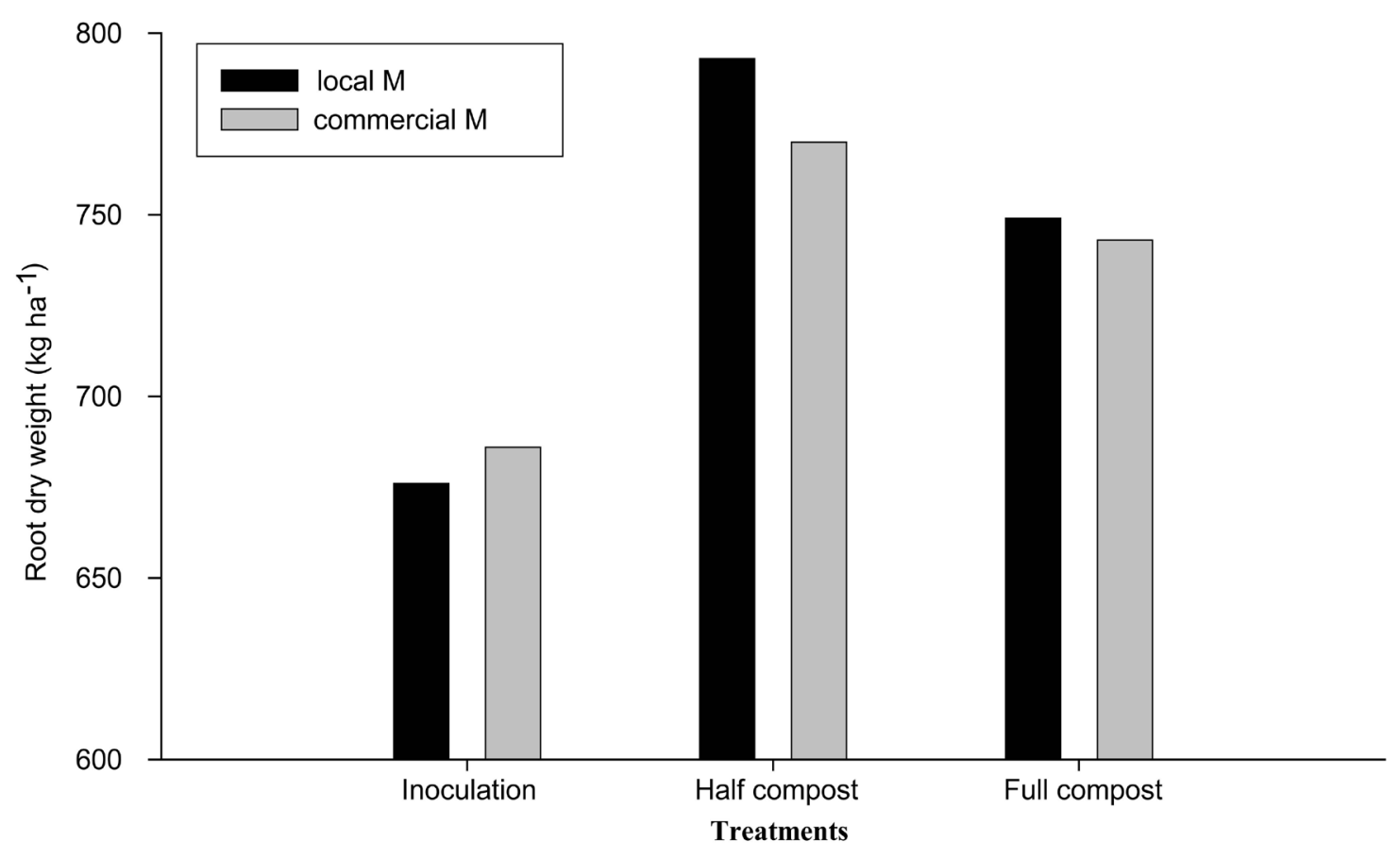

Figure 2. Effect of AMF inoculated with compost on root dry weight of berseem.

\subsection{Post Harvest Soil N, P and Micronutrients Contents}

Data of post harvest soil N, P and Zn, Cu, Mn and Fe contents as affected by the AMF inoculation with compost are presented in Table 3. The data indicated that the treatment of AMF-I inoculation with full dose of compost released maximum total $\mathrm{N}$ content of $1242 \mathrm{mg} \mathrm{kg}^{-1}$ followed by the AMF-II inoculation with full dose of compost. Maximum AB-DTPA extractable P content of $7.76 \mathrm{mg} \mathrm{kg}^{-1}$ was recorded in the treatments of AMF-II inoculation with full dose of compost followed by the treatment of AMF-I inoculation with full dose of compost. The data revealed that soil Zn content of $1.40 \mathrm{mg} \mathrm{kg}^{-1}$ was found in the treatments of AMF-I inoculation with full dose of compost followed by the AMF-II inoculation with full dose of compost. The treatment received AMF-I inoculation and full dose of compost released maximum Cu content of $4.30 \mathrm{mg} \mathrm{kg}^{-1}$ followed by the inoculation of AMF-II with full dose of compost. Maximum Mn content $10.20 \mathrm{mg} \mathrm{kg}^{-1}$ was recorded in the treatments of AMF-I inoculation with full dose of compost and AMF-II followed by the treatments of inoculation of AMF-II with full dose of compost. The maximum Fe content of $3.80 \mathrm{mg} \mathrm{kg}^{-1}$ was found in the treatment of AMF-I inoculation with half dose of compost followed by of inoculation of AMF-I with full dose of compost. Similar results were recorded by Habashy et al. [29] that highest P content was obtained in the treatment of inoculation of AMF with compost over alone inoculation of AMF or alone compost application and stated that when organic matter was added to the calcareous soil and thus may applied organic matter released phosphate in the soil and more available to the plant.

\subsection{Plant $\mathbf{N}$ and $\mathbf{P}$ Concentrations and Their Uptakes}

Data regarding plants $\mathrm{N}$ and $\mathrm{P}$ concentrations and their uptakes by berseem as affected by AMF inoculation with compost are presented in Table 4. The data indicated that maximum plant $\mathrm{N}$ uptake of $173 \mathrm{~kg} \mathrm{ha}^{-1}$ was found in the treatment of AMF-II inoculation with full dose of compost, which was higher significantly $(\mathrm{P} \leq 0.05)$ by $268 \%$ and $188 \%$, respectively over control and $\mathrm{N}$ and $\mathrm{K}$ fertilizers followed by inoculation of AMF-II with half dose of compost (Figure 3). Maximum P uptake $17.47 \mathrm{~kg} \mathrm{ha}^{-1}$ was noted in treatment of AMF-II inoculated with full dose of compost (Table 4 ) and increased significantly $(\mathrm{P} \leq 0.05)$ by $308 \%$ over control and $229 \%$ over $\mathrm{N}$ and $\mathrm{K}$ fertilizers followed by inoculation of AMF-II with half dose of compost (Figure 4). El-Goud [30] investigated that highest uptake of $\mathrm{N}$ was found in the treatment $100 \%$ compost and $100 \% \mathrm{~N}$ inoculated with AMF and maximum P uptake in the treatment 75\% C and 100\% inoculated with AMF. Lambert et al. [35] reported 
Table 3. Post harvest soil N, P and micronutrients contents as affected by AMF inoculation with compost.

\begin{tabular}{|c|c|c|c|c|c|c|}
\hline \multirow{3}{*}{ Treatments } & & \multicolumn{5}{|c|}{ AB-DTPA extractable } \\
\hline & Total N & $\mathrm{P}$ & $\mathrm{Zn}$ & $\mathrm{Cu}$ & Mn & $\mathrm{Fe}$ \\
\hline & \multicolumn{6}{|c|}{ soil contents $\left(\mathrm{mg} \mathrm{kg}^{-1}\right)$} \\
\hline Control (No fertilizer) & $480 e^{*}$ & $5.40 \mathrm{~d}^{*}$ & $0.98 \mathrm{~d}^{*}$ & $3.50 \mathrm{~d}^{*}$ & $7.70 c^{*}$ & $3.20 \mathrm{~d}^{*}$ \\
\hline $\mathrm{N}$ and $\mathrm{K}$ fertilizer (Basal dose) & $785 \mathrm{~d}$ & $5.66 \mathrm{~d}$ & $1.13 \mathrm{~cd}$ & $3.61 \mathrm{~d}$ & $8.00 \mathrm{c}$ & $3.40 \mathrm{~cd}$ \\
\hline Full dose of compost & $913 \mathrm{~cd}$ & $6.50 \mathrm{c}$ & $1.23 \mathrm{bc}$ & $3.73 \mathrm{~cd}$ & $8.30 \mathrm{c}$ & $3.43 \mathrm{~cd}$ \\
\hline Indigenous AMF (AMF-1) & $918 \mathrm{~cd}$ & 6.76 bc & 1.25 bc & 3.75 cd & $8.33 \mathrm{c}$ & $3.53 \mathrm{bc}$ \\
\hline Commercial AMF (AMF-II) & $956 \mathrm{~cd}$ & 6.63 bc & $1.23 \mathrm{bc}$ & $3.73 \mathrm{~cd}$ & $8.33 \mathrm{c}$ & $3.46 \mathrm{c}$ \\
\hline Half dose of compost + AMF-I & $1163 \mathrm{ab}$ & $7.23 \mathrm{abc}$ & $1.27 \mathrm{ab}$ & $4.10 \mathrm{abc}$ & $9.60 \mathrm{ab}$ & $3.80 \mathrm{a}$ \\
\hline Half dose of compost + AMF -II & $1146 \mathrm{ab}$ & $7.30 \mathrm{ab}$ & $1.26 \mathrm{abc}$ & $4.16 \mathrm{abc}$ & $9.66 \mathrm{ab}$ & $3.73 \mathrm{ab}$ \\
\hline Full dose of compost + AMF-I & $1242 \mathrm{a}$ & $7.66 \mathrm{a}$ & $1.40 \mathrm{a}$ & $4.30 \mathrm{a}$ & $10.20 \mathrm{a}$ & $3.65 \mathrm{abc}$ \\
\hline Full dose of compost + AMF-II & $1233 \mathrm{ab}$ & $7.76 \mathrm{a}$ & $1.35 \mathrm{ab}$ & $4.25 \mathrm{ab}$ & $9.93 \mathrm{ab}$ & $3.63 \mathrm{abc}$ \\
\hline Full dose of SSP & $1101 \mathrm{~b}$ & $7.30 \mathrm{a}$ & $1.23 \mathrm{ab}$ & $3.81 \mathrm{bcd}$ & $9.20 \mathrm{ab}$ & $3.55 \mathrm{abc}$ \\
\hline
\end{tabular}

*Means with different letter(s) in columns are significantly different at P $\leq 0.05$. N-P-K $=120-90-60 \mathrm{~kg} \mathrm{ha}^{-1}$, respectively, compost $=4500 \mathrm{~kg} \mathrm{ha}^{-1}$, AMF-1 $=70$ spores pot ${ }^{-1}$, AMF-II $=10 \mathrm{ml} \mathrm{pot}^{-1}$.

Table 4. Plant $\mathrm{N}$ and $\mathrm{P}$ uptake as influenced by AMF inoculation with compost.

\begin{tabular}{|c|c|c|}
\hline \multirow{2}{*}{ Treatments } & $\mathrm{N}$ & $\mathrm{P}$ \\
\hline & \multicolumn{2}{|c|}{ Plant uptake $\left(\mathrm{kg} \mathrm{ha}^{-1}\right)$} \\
\hline Control (No fertilizer) & $47 \mathrm{e}^{*}$ & $4.28 \mathrm{~d}^{*}$ \\
\hline $\mathrm{N}$ and $\mathrm{K}$ fertilizer (basal dose) & $60 \mathrm{e}$ & $5.30 \mathrm{~d}$ \\
\hline Full dose of compost & $85 \mathrm{~d}$ & $7.62 \mathrm{c}$ \\
\hline Indigenous AMF inoculation (AMF-1) & $98 \mathrm{~d}$ & $7.79 \mathrm{c}$ \\
\hline Commercial AMF inoculation (AMF-II) & $95 \mathrm{~d}$ & $7.69 \mathrm{c}$ \\
\hline Half dose of compost + AMF-I & 155 abc & 16.59 a \\
\hline Half dose of compost + AMF -II & 170 ab & $17.00 \mathrm{a}$ \\
\hline Full dose of compost + AMF-I & $147 \mathrm{bc}$ & 16.55 a \\
\hline Full dose of compost + AMF-II & 173 a & 17.47 a \\
\hline Full recommended dose of SSP & $132 \mathrm{c}$ & $14.16 \mathrm{~b}$ \\
\hline
\end{tabular}

*Means with different letter(s) in columns are significantly different at $\mathrm{P} \leq 0.01$. N-P-K $=120-90-60 \mathrm{~kg} \mathrm{ha}^{-1}$, respectively, compost $=4500 \mathrm{~kg} \mathrm{ha}^{-1}$, $\mathrm{AMF}^{-1}=70$ spores pot ${ }^{-1}$, AMF-II $=10 \mathrm{ml} \mathrm{pot}^{-1}$

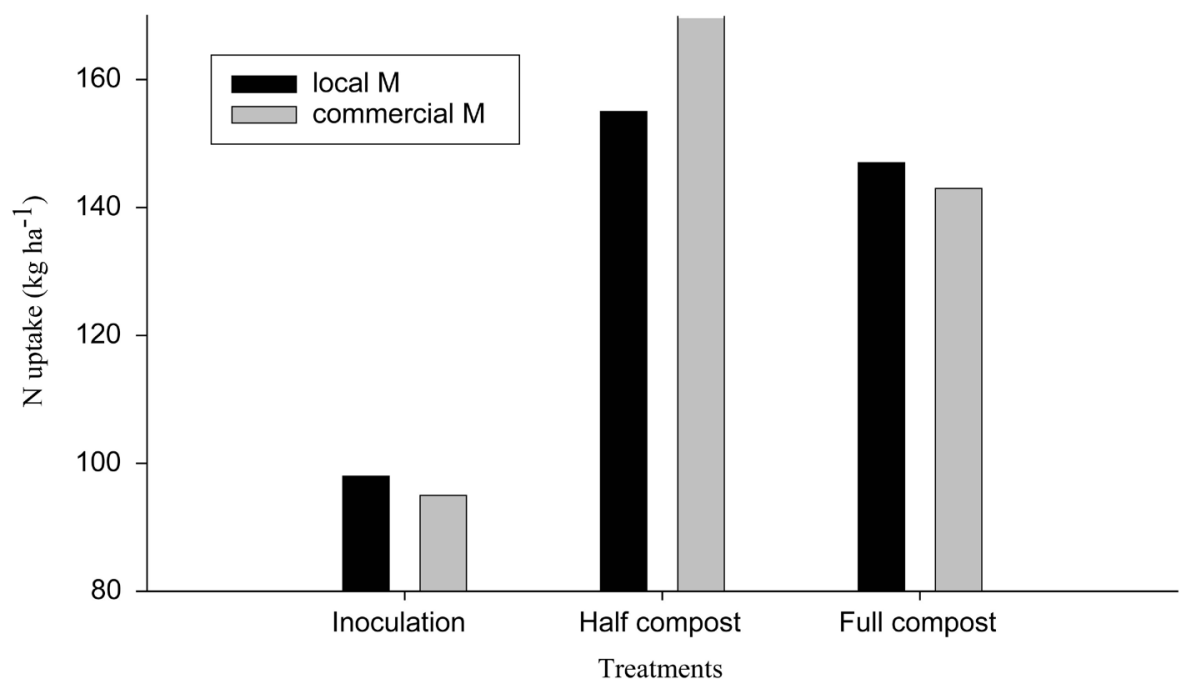

Figure 3. N uptake by berseem as affected by AMF inoculation with compost. 


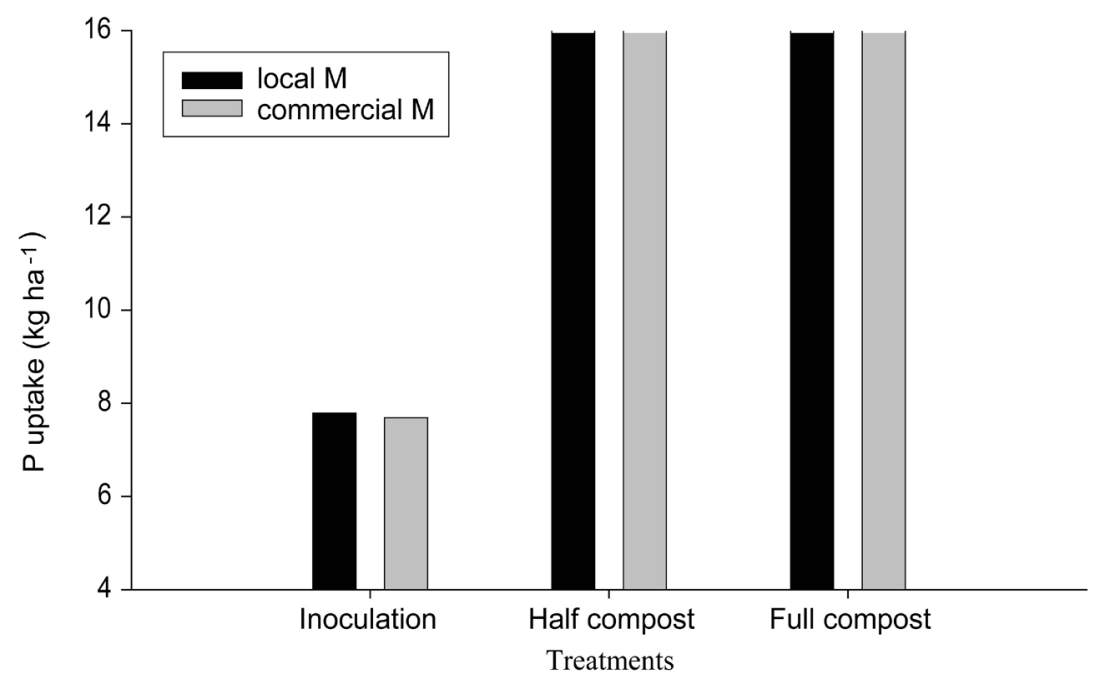

Figure 4. P uptake by berseem as affected by AMF inoculation with compost.

that AMF increased uptake of immobile nutrients such as $\mathrm{P}, \mathrm{Cu}$ and $\mathrm{Zn}$. The study conducted by Maksoud et al. [36] their result indicated that leaf P content was significantly increased by inoculation of AMF with rock phosphate. Habashy et al. [29] reported that $\mathrm{P}$ uptake increased when organic matter was added to the alkaline calcareous soil and thus may applied organic matter released phosphate in soil and more available to the plant. Sharif and Jan [33] found that the inoculation of AMF with rock phosphate was significantly increased the uptakes of $\mathrm{N}$ and P. Sharif et al. [34] reported that $\mathrm{N}$ uptake by wheat significantly increased with inoculation of AMF alone and in combination with poultry manure (PM), farmyard manure (FYM) and humic acid (HA).

\subsection{Plants Micronutrients Uptakes}

Plants $\mathrm{Zn}, \mathrm{Cu}, \mathrm{Fe}$ and Fe uptakes by berseem plants as affected by AMF inoculation with compost are presented in Table 5. The data revealed that maximum plants $\mathrm{Zn}$ uptake of $286 \mathrm{~g} \mathrm{ha}^{-1}$ was found in the treatment of inoculation of AMF-II with full dose of compost, which was significantly $(\mathrm{P} \leq 0.05)$ higher by $191 \%$ and $138 \%$, respectively over control and $\mathrm{N}$ and $\mathrm{K}$ fertilizers followed by inoculation of AMF-II with half dose of compost (Figure 5(a)). The data showed that maximum Cu uptake by berseem of $59 \mathrm{~g} \mathrm{~kg} \mathrm{ha}^{-1}$ was recorded in the treatment of inoculation of AMF-II with half dose of compost and increased significantly ( $\mathrm{P} \leq 0.05$ ) by $300 \%$ over control and 222\% over N and K fertilizers followed by inoculation of AMF-II with full dose of compost (Figure 5(b)). Maximum Mn uptake of $1225 \mathrm{~g} \mathrm{ha}^{-1}$ was noted in the treatment which inoculated with AMF-I half dose compost, which was significantly ( $\mathrm{P} \leq 0.05$ ) higher by $192 \%$ and $148 \%$, respectively over control and $\mathrm{N}$ and $\mathrm{K}$ fertilizers followed by inoculation of AMF-II with full dose compost (Figure 5(c)). Maximum Fe uptake by berseem of $643 \mathrm{~g} \mathrm{ha}^{-1}$ was found in the treatment of inoculation of AMF-II with half dose of compost and was increased significantly ( $\mathrm{P} \leq 0.05$ ) by $249 \%$ over control and $161 \%$ over $\mathrm{N}$ and $\mathrm{K}$ fertilizers followed by inoculation of AMF-I with half dose of compost (Figure 5(d)). Lambert et al. [35] reported that AMF increased uptake of Cu and Zn.

\subsection{Soil Spores Density of AMF and Their Roots Infection Intensity in Berseem Crop}

Data in Table 6 showed soil spores density and their roots infection intensity in berseem crop as influenced by AMF inoculation with composts in the area under investigations. Data showed that maximum AMF spores density of 27 spores per $20 \mathrm{~g}$ soil was observed in the treatment received inoculation of AMF-I and full dose of compost, which was significantly ( $\mathrm{P} \leq 0.05$ ) increased by $80 \%$ and $69 \%$, respectively over control and $\mathrm{N}$ and $\mathrm{K}$ fertilizers followed by the treatments of inoculation of AMF-I with half dose of compost and inoculation of AMF-II with half dose of compost. The highest berseem roots infection intensity $37 \%$ was observed in the treatment of AMF-I inoculation with full dose of compost and was significantly $(\mathrm{P} \leq 0.05)$ higher by $85 \%$ over control and $60 \%$ over $\mathrm{N}$ and $\mathrm{K}$ fertilizers followed by the treatment which received AMF-I inoculation with half dose of compost. Isolated spores were identified according to the procedure as described by Schenck and Parez 


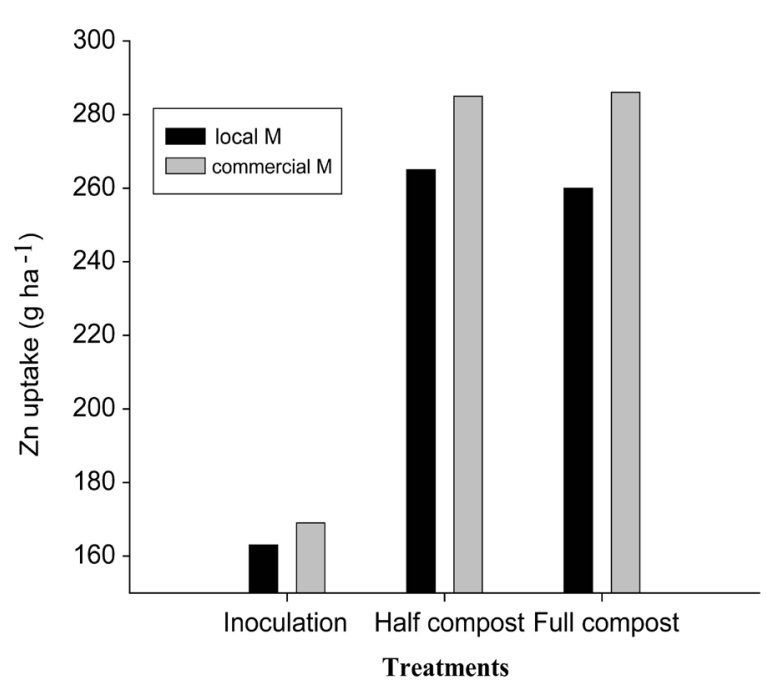

(a)

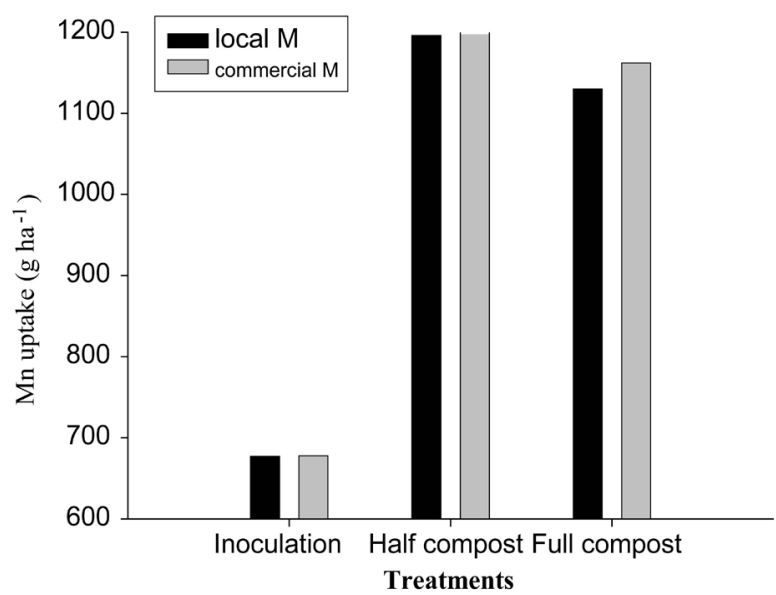

(c)

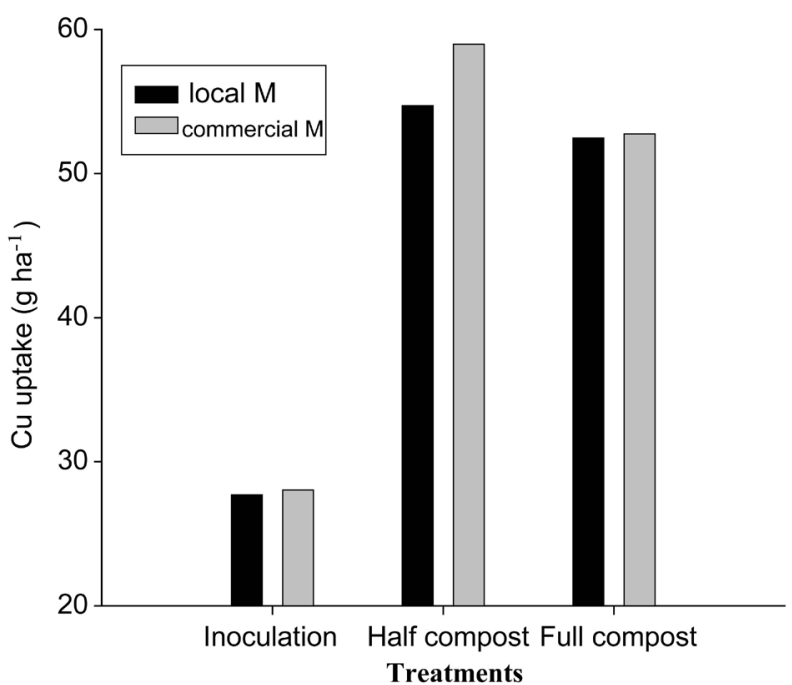

(b)

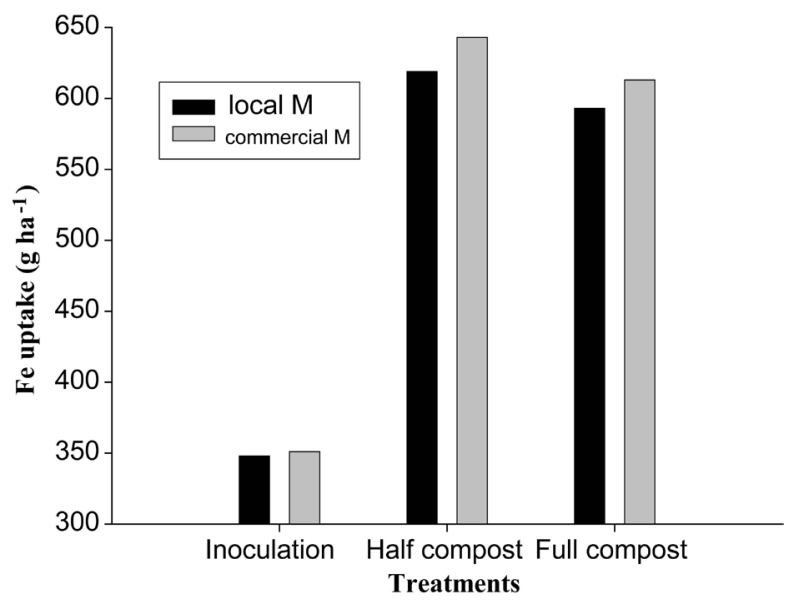

(d)

Figure 5. Plants uptake of $\mathrm{Zn}, \mathrm{Fe}, \mathrm{Cu}$ and $\mathrm{Mn}$, respectively as affected by AMF inoculation with compost.

Table 5. Plants micronutrients uptakes of berseem plants as affected by AMF inoculationwith compost.

\begin{tabular}{|c|c|c|c|c|}
\hline \multirow{2}{*}{ Treatments } & $\mathrm{Zn}$ & $\mathrm{Fe}$ & $\mathrm{Cu}$ & $\mathrm{Mn}$ \\
\hline & \multicolumn{4}{|c|}{ __ Plant uptake $\left(\mathrm{g} \mathrm{ha}^{-1}\right)$} \\
\hline Control (No fertilizer) & $98 d^{*}$ & $14.76 \mathrm{~d}^{*}$ & $420 \mathrm{~d}^{*}$ & $184 c^{*}$ \\
\hline $\mathrm{N}$ and $\mathrm{K}$ fertilizer (basal dose) & $120 \mathrm{~d}$ & $18.29 \mathrm{~d}$ & $493 \mathrm{~d}$ & $246 c$ \\
\hline Full dose of compost & 161 c & $27.82 \mathrm{c}$ & $686 \mathrm{c}$ & $339 \mathrm{~b}$ \\
\hline Indigenous AMF(AMF-1) & 163 c & $27.70 \mathrm{c}$ & 677 c & $348 \mathrm{~b}$ \\
\hline Commercial AMF (AMF-II) & 169 c & $28.03 \mathrm{c}$ & $678 \mathrm{c}$ & $351 \mathrm{~b}$ \\
\hline Half dose of compost + AMF-I & $265 a b$ & $54.70 \mathrm{ab}$ & 1196 a & $619 \mathrm{a}$ \\
\hline Half dose of compost + AMF -II & 285 a & 58.98 a & 1225 a & $643 \mathrm{a}$ \\
\hline Full dose of compost + AMF-I & $260 \mathrm{ab}$ & $52.47 \mathrm{ab}$ & $1130 \mathrm{ab}$ & $593 \mathrm{a}$ \\
\hline Full dose of compost + AMF-II & 286 a & $52.75 \mathrm{ab}$ & $1162 \mathrm{ab}$ & $613 \mathrm{a}$ \\
\hline Full recommended dose of SSP & $250 \mathrm{~b}$ & $51.68 \mathrm{~b}$ & $988 \mathrm{~b}$ & $591 \mathrm{a}$ \\
\hline
\end{tabular}

"Means with different letter(s) in columns are significantly different at $\mathrm{P} \leq 0.05$. N-P-K $=20-90-60 \mathrm{~kg} \mathrm{ha}^{-1}$, respectively, compost $=4500 \mathrm{~kg}$ ha ${ }^{-1}$, AMF-1 $=70$ spores pot ${ }^{-1}$, AMF-II $=10 \mathrm{ml} \mathrm{pot}^{-1}$. 
Table 6. Soil spores density and roots infection intensity in berseem crop as affected by AMF inoculation with compost.

\begin{tabular}{ccc}
\hline Treatments & AMF spores density (20 g soil) & AMF root infection intensity (\%) \\
\hline Control (No fertilizer) & $15 \mathrm{~d}^{*}$ & $20 \mathrm{e}^{*}$ \\
N and K fertilizer ( Basal dose) & $16 \mathrm{~d}$ & $23 \mathrm{de}$ \\
Full dose of compost & $17 \mathrm{~d}$ & $26 \mathrm{cde}$ \\
Indigenous AMF (AMF-I) & $21 \mathrm{c}$ bcd & $28 \mathrm{bcd}$ \\
Commercial AMF (AMF-II) & $21 \mathrm{c}$ & $35 \mathrm{ab}$ \\
Half dose of compost + AMF-I & $25 \mathrm{ab}$ ab \\
Half dose of compost + (AMF-II) & $25 \mathrm{ab}$ & $37 \mathrm{a}$ \\
Full dose of compost + AMF-I & $27 \mathrm{a}$ & $29 \mathrm{bcd}$ \\
Full dose of compost + AMF-II & $23 \mathrm{~b}$ & $25 \mathrm{de}$ \\
Full dose of SSP & $20 \mathrm{c}$ & \\
\hline
\end{tabular}

"Means with different letter(s) in columns are significantly different at $\mathrm{P} \leq 0.01$. N-P-K $=120-90-60 \mathrm{~kg} \mathrm{ha}^{-1}$, respectively, compost $=4500 \mathrm{~kg} \mathrm{ha}^{-1}$, $\mathrm{AMF}^{-1}=70$ spores pot ${ }^{-1}$, AMF-II $=10 \mathrm{ml} \mathrm{pot}^{-1}$.

[27]. Spores were dominated with Glomus intraradices, where as the spores of G. fasiculatum and G. mossea were present in minor quantity. The result of Habashy et al. [29] showed increased spore density and mycorrhizal root colonization gradually with the inoculation of AMF and organic waste compost, while significantly increased with the organic compost alone comparing to control one and also increased significantly by combined inoculation of AMF and compost over control and AMF or compost alone. Sharif and Jan [33] reported that mycorrhizal spore density and root infection intensity increased by inoculation of AMF and application of RP. The endomycorrhizal fungi are obligate symbiotic fungi, the hyphae of which develop mycelia, arbuscules and in most fungal genera vesicles in roots. Phosphorus is the second essential macro nutrient after nitrogen required for the growth of plant and found in organic and inorganic form. Due to its low solubility and mobility plant cannot utilize phosphorus is an in organic or complex form [37]. Inorganic P present in the soil, which is readily available to the plant, but in limited amount. Thus AMF enhance the nutrient uptake through its external hyphae into the surrounding soil and hydrolyzed unavailable source of phosphorus with the help of secreted enzymes such as phosphate [37]. These fungi dissolve relatively insoluble nutrients more efficiently even from very low nutrient concentration because of their ability to produce organic acids, exploration of more area beyond the root zone and release of $\mathrm{CO}_{2}$. Mycorrhizal fungi are beneficial symbiotic microorganisms with their extra metrical hyphae, which increase growth and yield of most crops. The AMF improve soil structure and thus enhance physically, chemically and biological soil quality and improve soil physical structure. Mycorrhiza play significant role in the uptake of P from RP and mycorrhizal plants are more effective in the utilization of RP than nonmycorrhizal plants. According to Ness and Vlek [38] only mycorrhizal maize took up phosphorus from hydroxyl-apatite, and that $\mathrm{P}$ subsequently transferred to maize. Rock phosphate, being the cheapest source of $\mathrm{P}$, can be best utilized as P fertilizer only when it is dissolved properly by chemical or biological means. Compost is environmental friendly and cost effective technique of waste recycling [8]. The composted materials are better than raw materials due to C: N, C: P and C: K ratios. Microbes produce organic acid, hormones; enzymes which help in mineralization of nutrients including $\mathrm{P}$ which release from organic matter and available for plant uptake. Mycorrhizal inoculations with compost application are more effective in improving the physical properties of soil than inorganic fertilizer. The long term organic fertilizers and mycorrhizal inoculation could improve soil physical properties which are the indicator for development of roots and improvement of crop production [39].

\section{Conclusion}

It could be concluded from the results of the conducted experiment that berseem shoot and root yield were improved significantly by the inoculation of indigenous AMF with half dose of compost. Soil contents of N, P, Zn, $\mathrm{Cu}, \mathrm{Fe}$ and $\mathrm{Mn}$ were improved by the inoculation of AMF with compost. Plants uptakes of nutrients improved significantly AMF-I inoculation with compost. Improved soil spores density of AMF by their inoculation with compost showed positive correlation with root intensity of berseem. Inoculation of AMF with compost has potential to improve yield and plants N, P, Zn, Cu, Mn and Fe uptakes of berseem under given soil conditions. 


\section{References}

[1] Menge, J.A. and Timmer, L.W. (1982) Procedure for Inoculation of Plants Vesicular-Arbuscular Mycorrhizal in Laboratory. Green House and Field. In: Schenck, N.C., Ed., Methods and Principles of Mycorrhizal Research, American Phytopathological Society, St. Paul.

[2] Smith, S.E. and Read, D.J. (1997) Mycorrhizal Symbiosis. Elsevier Science, New York.

[3] Williamson, L.C., Ribrioux, S.P.C.P., Fitter, A.H., and Leyser, H.M.O (2001) Phosphate Availability Regulates Root System Architecture in Arabidopsis. Plant Physiology, 126, 875-882. http://dx.doi.org/10.1104/pp.126.2.875

[4] Mengel, K. and Kirkby, E.A (1987) Principles of Plant Nutrition. International Potash Institute, Berne, 588-594.

[5] Vance, C.P., Uhde-Stone, C. and Allan, D.L. (2003) Phosphorus Acquisition and Use: Critical Adaptations by Plants for Securing a Nonrenewable Resource. New Phytologist, 157, 423-447. http://dx.doi.org/10.1046/j.1469-8137.2003.00695.x

[6] Raghothama, K.G. and Karthikeyan, A.S. (2005) Phosphate Acquisition. In: Lambers, H. and Colmer, T.D., Ed., Root Physiology: From Gene to Function, Springer Netherlands, 37-49. http://dx.doi.org/10.1007/1-4020-4099-7 2

[7] Harris, J.N., New, P.B. and Martin, P.M. (2006) Laboratory Tests Can Predict Beneficial Effects of Phosphate-Solubilising Bacteria on Plants. Soil Biology and Biochemistry, 38, 1521-1526. http://dx.doi.org/10.1016/j.soilbio.2005.11.016

[8] Millner, P.D., Sikora, L.J., Kaufman, D D. and Simpson, M.E. (1998) Agricultural Uses of Biosolids and Other Recyclable Municipal Residues. USDA Agricultural Research Service Conservation Research Report, 9-38.

[9] Stewart, W.M., Hammond, L.L. and Van Kauwenbergh, S.J. (2005) Phosphorus as a Natural Resource. In: Sims, J.T. and Sharpley, A.N., Eds., Phosphorus: Agriculture and the Environment, American Society of Agronomy, Crop Science Society of America, and Soil Science Society of America, 3-22.

[10] Cordell, D., Drangert, J.O. and White, S. (2009) The Story of Phosphorus: Global Food Security and Food for Thought. Global Environmental Change, 19, 292-305. http://dx.doi.org/10.1016/j.gloenvcha.2008.10.009

[11] Ranjhan, S.K. (2001) Animal Nutrition in the Tropics. Vikas Publishing House Pvt. Ltd., New Delhi.

[12] Koehler, F.E., Moudre, C.D. and McNeal, B.L. (1984) Laboratory Manual for Soil Fertility. Washington State University, Pulman, 456-461.

[13] Mclean, E.O. (1982) Soil pH and Lime Requirement. In: Page, A.L., Ed., Methods of Soil Analysis. Part 2. Chemical and Microbiological Properties, American Society of Agronomy, Soil Science Society of America, 199-224.

[14] Richards, L.A. (1947) Diagnosis and Improvement of Saline and Alkaline Soils. Soil Science, 64, 432. http://dx.doi.org/10.1097/00010694-194711000-00013

[15] Nelson, D.W. and Sommers, L.E. (1996) Total Carbon, Organic Carbon, and Organic Matter. In: Sparks, D.L., Page, A.L., Helmke, P.A., Loeppert, R.H., Soltanpour, P.N., Tabatabai, M.A., Johnston, C.T. and Sumner, M.E., Eds., Methods of Soil Analysis. Part 3-Chemical Methods, Soil Science Society of America Inc., Madison, 961-1010.

[16] Bremner, J.M. (1996) Nitrogen-Total. In: Sparks, D.L., Page, A.L., Helmke, P.A., Loeppert, R.H., Soltanpour, P.N., Tabatabai, M.A., Johnston, C.T. and Sumner, M.E., Eds., Methods of Soil Analysis. Part 3-Chemical Methods, Soil Science Society of America Inc., Madison, 1085-1121.

[17] Soltanpour, P.N. and Schwab, A.P. (1977) A New Soil Test for Simultaneous Extraction of Macro- and Micro-Nuients in Alkaline Soils 1. Communications in Soil Science \& Plant Analysis, 8, 195-207. http://dx.doi.org/10.1080/00103627709366714

[18] Hauck, F.W. (1978) China: Recycling of Organic Wastes in Agriculture. Food and Agricultural Organization of the United Nations, Rome.

[19] BioMyc ${ }^{\mathrm{TM}}$ (2010) Production of AMF Spores and Hyphae. BioMycorrhizal Environment GmbH, Germany. www.BioMyc.de

[20] Walsh, L.M., and Beaton, J.D. (1977) Soil Testing and Plant Analysis. Soil Science Society of America, Inc., Wisconsin.

[21] Barber, S.A. (1995) Soil Nutrient Bioavailability: A Mechanistic Approach. John \& Wiley Sons, Inc., New York.

[22] Ryan, M.H., Norton, R.M., Kirkegaard, J.A., McCormick, K.M., Knights, S.E. and Angus, J.F. (2002) Increasing Mycorrhizal Colonisation Does Not Improve Growth and Nutrition of Wheat on Vertosols in South-Eastern Australia. Crop and Pasture Science, 53, 1173-1181. http://dx.doi.org/10.1071/AR02005

[23] Jackson, M.L.R. and Barak, P. (2005) Soil Chemical Analysis: Advanced Course. UW-Madison Libraries Parallel Press, USA.

[24] Brundrett, M.C. (1991) Mycorrhizas in Natural Ecosystems. Academic Press, Inc., San Diego. 
[25] Phillips, J.M. and Hayman, D.S. (1970) Improved Procedures for Clearing Roots and Staining Parasitic and Vesicular-Arbuscular Mycorrhizal Fungi for Rapid Assessment of Infection. Transactions of the British Mycological Society, 55, 158-161, IN16-IN18. http://dx.doi.org/10.1016/S0007-1536(70)80110-3

[26] Koske, R.E. and Gemma, J.N. (1989) A Modified Procedure for Staining Roots to Detect VA Mycorrhizas. Mycological Research, 92, 486-488. http://dx.doi.org/10.1016/S0953-7562(89)80195-9

[27] Schenck, N.C. and Perez, Y. (1990) Manual for Identification of Vesicular Arbuscular Mycorrhizal Fungi. (INVAM). University of Florida, Gainesville.

[28] Steel, R.G.D. and Torrie, J.H. (1980) Principles and Procedures of Statistics, a Biometrical Approach. McGraw-Hill Kogakusha, Ltd., Tokyo.

[29] Habashy, N.R., El-Khair, A.W.A. and Zaki, R.N. (2008) Effect of Organic and Bio-Fertilizers on Phosphorus and Some Micronutrients Availability in a Calcareous Soil. Research Journal of Agricultural and Biological Science, 4, 454-552.

[30] El-Goud, A.K.S.A. (2010) Effect of Endomycorrhizal Fungi and Compost on the Yield and Quality of Maize and Sunflower Plants in Poor Nutrients Soil. PhD Thesis, University of Kassel, Kassel.

[31] El-Sayed, S.E.M., Ramadan, H.M. and El-Fayoumy. M.E. (2006) Impact of Compost and Mineral Fertilizers Application on Cereal Crops in Calcareous Soil. Menofia Journal of Agricultural Research, 31, 1067-1085.

[32] Filho, P.F.M., de F. Vasconcellos, R.L. and Cardoso, E.J.B.N. (2011) Growth and Development of Jack-Bean and Pigeon-Pea in Cassiterirte Mine Spoil. Journal of Soil Science and Environmental Management, 2, 74-79.

[33] Sharif, M. and Jan, B. (2008) Growth and Nutrient Accumulation of Maize Plants as Affected by the Inoculation of AMF with Rock Phosphate. Soil and Environment, 27, 116-122.

[34] Sharif, M., Sarir, M.S., Bakht, J., Saud, S., Ali, A. and Ahmad, M. (2009) Response of Wheat to the Inoculation of Arbuscular Mycorrhizal Fungi in Salt Affected Soil. Sarhad Journal of Agriculture, 25, 209-216.

[35] Lambert, D.H., Baker, D.E. and Cole, H. (1979) The Role of Mycorrhizae in the Interactions of Phosphorus with Zinc, Copper, and Other Elements. Soil Science Society of America Journal, 43, 976-980. http://dx.doi.org/10.2136/sssaj1979.03615995004300050033x

[36] Maksoud, M.A., Haggag, L.F., Azzay, M.A. and Saad, R.N. (1994) Effect of VAM Inoculation and Phosphorous Application on Growth and Nutrient Content (P and K) of Tamarindus indica L. (Tamarind) Seedlings. Annals of Agricultural Science, 30, 355-363.

[37] Schachtman, D.P., Reid, R.J. and Ayling, S.M. (1998) Phosphorus Uptake by Plants: From Soil to Cell. Plant Physiology, 116, 447-453. http://dx.doi.org/10.1104/pp.116.2.447

[38] Ness, R.L.L. and Vlek, P.L.G. (2000) Mechanism of Calcium and Phosphate Release from Hydroxy-Apatite by Mycorrhizal Hyphae. Soil Science Society of America Journal, 64, 949-955. http://dx.doi.org/10.2136/sssaj2000.643949x

[39] Celik, I., Ortas, I. and Kilic, S. (2004) Effects of Compost, Mycorrhiza, Manure and Fertilizer on Some Physical Properties of a Chromoxerert Soil. Soil and Tillage Research, 78, 59-67. http://dx.doi.org/10.1016/j.still.2004.02.012 